\title{
SAGO PALM BIODIVERSITY IN SERAM ISLAND \\ MALUKU PROVINCE, INDONESIA
}

\section{BIODIVERSITAS TUMBUHAN SAGU DI PULAU SERAM, PROVINSI MALUKU, INDONESIA}

\author{
Samin Botanri ${ }^{1)}$, Dede Setiadi ${ }^{2)}$, Edi Guhardja ${ }^{2)}$, Ibnul Qayim ${ }^{2)}$, \\ Lilik B. Prasetyo ${ }^{3)}$ \\ ${ }^{1)}$ Fakultas Pertanian Univ. Darussalam Ambon, \\ Jl. Raya Waehakila Puncak Wara Ambon (97128) \\ ${ }^{2)}$ Departemen Biologi Fakultas MIPA IPB Bogor \\ ${ }^{3)}$ Departemen Konservasi Sumberdaya Hutan dan Ekowisata Fakultas Kehutanan IPB Bogor \\ Jl. Raya Dramaga, Bogor, Jawa Barat (16680) \\ Correspodence: saminunidar82@gmail.com
}

Accepted May, $11^{\text {th }}$ 2018/ Approved December, $9^{\text {th }} 2018$

\begin{abstract}
The number of sago palm species in Maluku Province becomes the current issue of biodiversity. The research aimed to clarify the species of sago palm in the Seram island, Maluku province. The research was conducted from March to November 2009 in three sample regions i.e. Luhu of Seram Bagian Barat (SBB) district, Sawai of Maluku Tengah (MT) district, and Werinama of Seram Bagian Timur (SBT) district. Genetic analysis was done at the laboratory of plant biology Inter Center University (ICU) Bogor Agricultural University. Variety of palm sagu was analyzed using index of similarity analysis for group similarity and Shannon-Wiener $\left(\mathrm{H}^{\prime}\right)$ index for biodiversity of species. Further, the genetic analysis used isozyme method showed that group of sago in Seram Island shared group similarity included index value ranging from 60.66-80.92\%. Based on the result of Shannon-Wiener $\left(\mathrm{H}^{\prime}\right)$ index, all growth phases of sago palm group in Seram Island generally indicated a very low $\mathrm{H}^{\prime}$ value ranging from $0.61-0.90$. Clearly, the genetic analysis illustrated there were only two kinds of sago species in Seram Island i.e. Metroxylon rumphii Mart. and $M$. sagus Rottb. The first species consists of three varieties i.e. 1) Microcanthum Becc., 2) Sylvestre Becc., and 3) Rotang Becc. Sago species of M. sagu Rottb. has solely one variety Molat Becc. Here, variety of Microcanthum is divided by two kinds of variety i.e. Tuni and Makanaro.
\end{abstract}

Key words : Biodiversity, Metroxylon, species, genetic, Seram island

\section{ABSTRAK}

Jumlah spesies tumbuhan sagu di provinsi Maluku masih mengalami perdebatan dalam bidang biodiversitas. Penelitian ini bertujuan untuk melakukan klarifikasi spesies sagu yang tumbuh dan berkembang di pulau Seram, provinsi Maluku. Penelitian berlangsung pada bulan MaretNovember 2009. Pengamatan dilakukan pada 3 wilayah sampel yaitu: Luhu Kab. Seram Bagian Barat (SBB), Sawai Kab. Maluku Tengah (MT), dan Werinama Kab. Seram Bagian Timur (SBT). Analisis genetik dikerjakan di laboratorium Biologi Tumbuhan Pusat Antar Universitas (PAU) IPB

ISSN : 2407-7933

Cite this as: Botanri, S. Setiadi, D. Guhardja, E. Qayim, I. \& Prasetyo, L. B. (2018). Sago palm biodiversity in Seram island Maluku province Indonesia. Jurnal Agro, 5(2), 86-94. https://doi.org/10.15575/2431 
Bogor. Keanekaragaman kelompok sagu dianalisis dengan menggunakan analisis kemiripan kelompok. Keanekaragaman spesies dianalisis menggunakan Indeks Keaneragaman ShannonWiener $\left(\mathrm{H}^{\prime}\right)$. Analisis genetik menggunakan metode isozim. Hasil analisis menunjukkan bahwa kelompok sagu di Pulau Seram memiliki kemiripan kelompok yang termasuk dalam kategori tinggi dengan nilai indeks berkisar antara 60,66-80,92\%. Hasil analisis indeks keanekaragaman spesies menurut indeks Shannon-Wiener $\left(\mathrm{H}^{\prime}\right)$ pada semua fase pertumbuhan menunjukkan bahwa indeks keanekaragaman spesies vegetasi dalam kelompok sagu di Pulau Seram secara umum termasuk dalam kategori sangat rendah dengan nilai $\mathrm{H}^{\prime}$ berkisar antara 0,61-0,90. Hasil analisis genetik menunjukkan bahwa di Pulau Seram Maluku hanya terdapat dua spesies sagu, yaitu Metroxylon rumphii Mart. dan $M$. sagus Rottb. Spesies yang pertama terdiri dari tiga varietas, yaitu: 1) Microcanthum Becc., 2) Sylvestre Becc., dan 3) Rotang Becc. Sedangkan spesies M. sagu Rottb. hanya memiliki satu varietas yakni Molat Becc. Varietas Microcanthum terbagi atas dua subvarietas, yaitu Tuni dan Makanaro.

Kata kunci : Biodiversitas, Metroxylon, spesies, genetik, pulau Seram

\section{INTRODUCTION}

Biodiversity calls for all the living species on the earth including not only flora, fauna, fungi and microorganism, but all the genetic materials that these living species and ecology system variety bring on their living place as well. Kartono (2008) described biodiversity has three levels, i.e. a). Biodiversity of genetic, referring to genetic information existed individually, b). Biodiversity of species, explaining the amount of living species in a certain place, and c). Biodiversity of ecosystem, illustrating the habitat variety, biological community, and ecology processes existed in some specific ecosystems.

Related to the biodiversity of sago palm, according to Beccari (1918) in Flach (1997), genus of Metroxylon has two groups. The first one is the sago palm having row scales of fruit peel as many as 18 which then grouped in Eumetroxylon. Another one sets up for the number of row scales of fruit peel ranging from 24-29 catagorized into Coelococcus. Eumetroxylon has two species i.e. Metroxylon sagu Rottb. and Metroxylon rumphii Mart while Coelococcus consists of seven species i.e. M. squarosum Becc., $M$. warburgii Heim., $M$. upoluense Becc., $M$. vitiense Benth et Hook, M. amicarum Becc.,
M. salomonense Becc., and $M$. bougainvillense Becc.

According to Heyne (1950) in Notohadiprawiro \& Louhenapessy (1993) he defined that sago palm is the genuine sago included in genus of Metroxylon. This genuine sago is then categorized into two main groups based on the existence of thorn in the leaf stem. The first group defined as thorny palm covers $M$. rumphii Mart, as the main species in this group, $M$. Longispinum Mart., M. Microcanthum Mart., and $M$. Sylvestre Mart. Standing on another species which doesn't have thorn is $M$. sagu Rottb and is the one with various forms.

McClatchey et al. (2006) conducted a botanical description on sago palm genus of Metroxylon and divided it into six species i.e. 1) M. amicarum (H.Wendland) Beccari, 2) M. Paulcoxii McClatchey, 3) M. sagu Rottboell, 4) $M$. salomonense (Warburg) Beccari, 5) $M$. vitiense ( $\mathrm{H}$. Wendland) $\mathrm{H}$. Wendland ex Bentham \& Hooker f., and 6) M. warburgii (Heim) Beccari. The spreading region of this various sago palms covers South East Asia, Melanesia, and some islands in Micronesia and Polynesia. Based on the spreading of sago palm map illustrated by Mc Clatchey, it is clear that Indonesia, PNG, and part of islands in South Phillipine has 
solely one species of sago palm: $M$. sagu Rottb.

According to the book written by Louhenapessy (2006); Bintoro (2008); and Rostiwati et al. (2008), it found that Maluku island has five kinds of sago palm i.e. 1) Metroxylon rumphii Mart. (Tuni), 2) M. sagu Rottb. (Molat), 3) M. Sylvestre Mart. (Ihur), 4) M. Longispinum Mart. (Makanaro), and 5) M. Microcanthum Mart. (Duri Rotan). Various perspectives given by some scholars above depicted some pros and cons toward the number of sago palm. That issue encourages another study considering necessary to clarify the exact number of sago palm species cultivation in Maluku province particularly in Seram island.

\section{MATERIAL AND METHOD}

\section{Place and Time of The Research}

The research was conducted in Seram island known as the biggest island in Maluku province with $\pm 18.000 \mathrm{~km}^{2}$. The research was also conducted for 9 months started from March to November 2009. The observation was conducted into three sample regions: 1) Luhu of Seram Bagian
Barat (SBB) District, 2) Sawai of Maluku Tengah (MT) District, dan 3) Werinama of Seram Bagian Timur (SBT) District. Genetic analysis was analyzed in the plant biology laboratory of Inter Center University (ICU) Bogor Agricultural University.

\section{Material and Method of The Research}

In this study, the sago palm was located in vegetation exposure where several various of plants grow up together in uncertain class or group. The sago palm group is equalized to sample region, so each of sample region was assumed as a group.

The observation activity was conducted in a square equipment. The size of the square equipment was suitable with the phase of vegetation sprouting. For seedling, the observations was done on the square equipment of $2 \mathrm{~m} \times 2 \mathrm{~m}$, phase of clum (sapling) measured for $5 \mathrm{~m} \times 5 \mathrm{~m}$, pole of 10 $\mathrm{m} \times 10 \mathrm{~m}$, and tree of $20 \mathrm{~m} \times 20 \mathrm{~m}$. Vegetation observation of study biodiversity was conducted through some stages as described in Figure 1. The observed variables were: a) Plantation species, b) The number of each species, c) The density of each sample unit, and d) coverage.

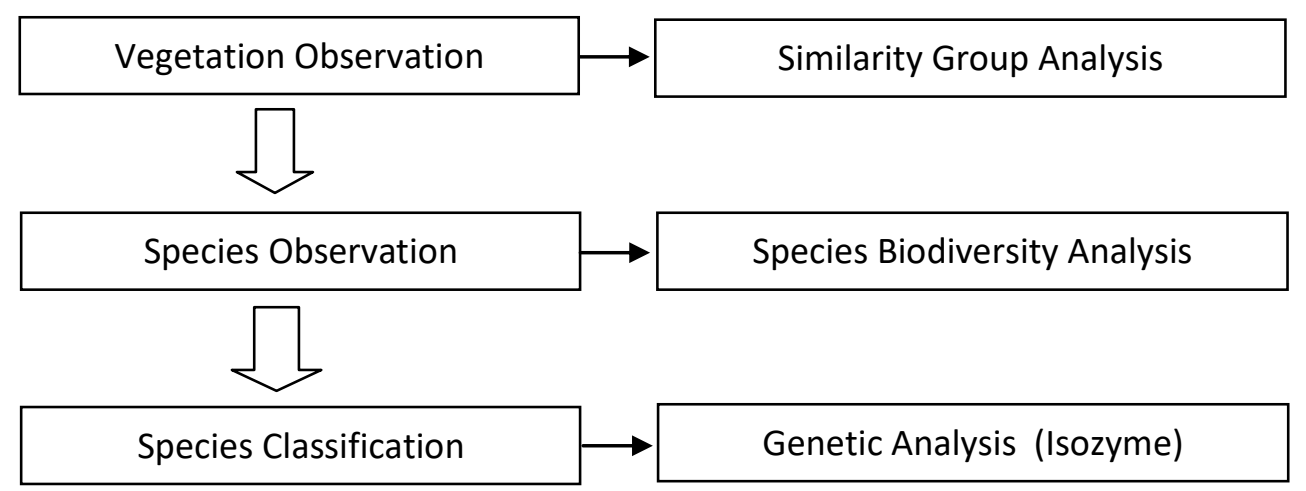

Figure 1. Study Stage of Sago Palm Biodiversity

\section{Biodiversity of Group}

To explain biodiversity of group of sago palm in Seram island, Maluku province, analysis of group similarity was used where as one sample region was assumed as sago group as well. The analysis of group similarity was conducted through index of 
similairty (IS) (Smith 1980 in Setiadi et al. 1989), given as :

$$
I S=\frac{2 w}{(a+b)} \times 100 \%
$$

where :

IS : Index of Similarity

a : Number of important value of the first stand

b : Number of important value of the second stand the smallest number for each observed stand

The similarity level between sago groups divided into some criteria i.e. very high index of similarity (IS > $75 \%$ ), high index of similairty $(50 \%<$ IS $<75 \%$ ), low index of similarity $(25 \%<$ IS $<50 \%)$, and very low index of similarity (IS < 25 \%) (Krebs, 1999).

\section{Biodiversity of Species}

This analysis aimed to explain biodiversity of species for each sago group in sample regions. The number of index of biodiversity of species (Shannon-Wiener $\mathrm{H}^{\prime}$ ) was set up as below (Ludwig dan Reynolds, 1988) :

where :

$$
H^{\prime}=-\sum[(n . i / N) \log (n . i / N)]
$$

$\mathrm{H}^{\prime} \quad$ : Index of Biodiversity

n.i : important value of each kind

$\mathrm{N}$ : total number of important value

Theoretically, index of biodiversity of Shannon $\left(\mathrm{H}^{\prime}\right)$ ranged from 0-7. If the value of $H^{\prime} \leq 1$, then it could be concluded that biodiversity of the species was very low. If the value was $1<\mathrm{H}^{\prime} \leq 2$, it was said that the index of biodiversity was low, if the value was $2<\mathrm{H}^{\prime} \leq 3$ then index of biodiversity was included as medium, and if the value was 3 $<\mathrm{H}^{\prime} \leq 4$ then index of biodiversity was assumed high, and if the value of $\mathrm{H}^{\prime}>4$ then the index of biodiversity was catagorized as very high (Soegianto, 1994).

\section{Biodiversity of Genetic}

The genetic analysis aimed to classify the sago palm species as there was tendency different point of view related to the number of sago palm species existed in Seram island Maluku province particularly and in Indonesia generally. The particular analysis to explain these difference point of view was conducted through a method of tapioca flour gel electrophoresis or named as isozyme analysis (Hartana, 2003). The method utilized some enzymes i.e. 1) Aspartat Amino Transferase (AAT), 2) Phosphatase Acid (ACP), 3) Peroxide (PER), and 4) Esterase (EST).

\section{RESULT AND DISCUSSION}

The result was used to clarify sago palm species in Seram island, Maluku province. The species clarification was according to two identified point of views, this research result and sago experts and clarification described by Beccari (1918) in Flach (1997). The division of clarification of sago palm species in Seram island was illustrated as follow in Table 1.

\begin{tabular}{|c|c|c|c|c|c|}
\hline \multirow[t]{2}{*}{ No } & \multirow[t]{2}{*}{ Name of area } & \multirow{2}{*}{$\begin{array}{l}\text { Name of species in } \\
\text { general* }\end{array}$} & \multicolumn{3}{|c|}{$\begin{array}{l}\text { Name of species according to Beccari } \\
\text { (1918) in Flach (1997) }\end{array}$} \\
\hline & & & Species & Variety & Subvar. \\
\hline 1. & Tuni sagu & M. rumphii Mart. & M. rumphii Mart. & Micracanthum Becc. & Tuni \\
\hline 2. & Makanaro sagu & M. longispinum Mart. & M. rumphii Mart. & Micracanthum Becc. & Makanaro \\
\hline 3. & Ihur sagu & M. sylvestre Mart. & M. rumphii Mart. & Sylvestre Becc. & - \\
\hline 4. & Durirotan sagu & M. micracanthum Mart. & M. rumphii Mart. & Rotang Becc. & - \\
\hline 5. & Molat sagu & M. sagu Rottb. & M. sagu Rottb. & Molat Becc. & - \\
\hline
\end{tabular}

Table 1. Species of sago palm in Seram island, Maluku

Sources: * Haryanto and Pangloli (1992); Louhenapessy (2006); Bintoro (2008); Rostiwati et al. (2008). 
Luhu-SBB area I, Sawai-MT sample area II and Werinama-SBT as sample area III showed that the sago palm groups in Seram island shared the index of similarity included as high category ranged from $60.66-80.92 \%$. (average $65.76 \%$ ) (Table 2).Based on the cultivation phase, it showed that the highest similarity of the group of sago obtained on the weaning phase reaching $74.33 \%$ and the lowest similarity of group respectively showed on pole phase for $58.69 \%$, seedling phase for $62.41 \%$, and tree phase for $67.61 \%$. The similarity index of group among sample regions in all phases of sago growth showed a high category of sago species index of similarity in Seram island, Maluku province with index of $65.76 \%$. The number showed that there is a natural similarity of sago group in Seram island. The high value of similarity index was caused by the formation of cluster which grows massively through longitudinal rhyzome growth in all sample areas or regions. Thus, the longitudinal rhyzome formed a new individual own cluster.

Table 2. Index of similarity of sago group in Seram island, Maluku province

\begin{tabular}{llllll}
\hline \multirow{2}{*}{ No. } & Cultivation Phase & \multicolumn{4}{c}{ Index of Group Similarity (\%) } \\
\cline { 3 - 5 } & & I x II & I x III & II x III & Mean \\
\hline 1. & Tree & 60.95 & 60.95 & 80.92 & 67.61 \\
2. & Pole & 57.14 & 57.52 & 61.42 & 58.69 \\
3. & Sapihan & 74.91 & 71.60 & 76.47 & 74.33 \\
4. & Seedling & 65.92 & 60.66 & 60.66 & 62.41 \\
\hline & Mean & 64.73 & 62.68 & 69.87 & 65.76 \\
\hline
\end{tabular}

Note: Data was gathered from the data mean of Luhu Western Seram sample area I, Sawai Central Maluku sample area II, and Werinama Eastern Seram sample area III, 2009.

A high value of IS in Seram island lies on the similarity of either growth environment or habitat. This condition will be placed by homogen individual creature also from the same species, as that creature has naturally developed adaptation mechanism and tolerance toward its own habitat. The similarity of vegetation group of sago in Seram island, Maluku province is propelled also by the society cultivating activity and growing sago palm sporadically over thousand years ago. It is in line to Loveless (1983) in Setiadi (2005) stated that other factors determining the existence of botany species or community is not only caused as a part of the influence of physics and chemistry factor, but also both animals and human take a big contribution to the growth of vegetation itself.

\section{Biodiversity of Species Level}

The index analysis of species biodiversity according to Shannon $\left(\mathrm{H}^{\prime}\right)$ index to all the phases of sago growth in sample regions depicted the fact that index of species biodiversity was included as very low index given as $\mathrm{H}^{\prime}$ ranging from $0.61-0.90$, except for seedling phase in sample first region of Luhu-Western Seram with $\mathrm{H}^{\prime}$ value 1.18 (Table 3).

Generally, index of species biodiversity in Seram island, Maluku province is included as very low category. It means that sago palm groups spread in every sample regions does not share any different on the index of species biodiversity. This phenomenon provides a clue that the group of sago palm cultivated naturally in Seram island, Maluku province reached both climax and stable group. Barbour et al. (1987) made the point that species biodiversity is the important 
species giving an important information related to the activity of one specific group. He also explained that the wider the sample area, the more species will be located. Thus, the high value of species index biodiversity will then be higher. Low index value of species biodiversity generally met climax group units. In addition, a very stable group, widespread regional and homogen, has lower index value of species biodiversity as well compared to mozaic forest form. Sometimes, the value index is regionally affected by fire, wind, flood, infection, and human intervention periodically. Usually, after the disturbance is over, the increase on the species biodiversity reached a point where the group also has a climax. Then, the appearance of climax will tend the decrease of biodiversity index.

Table 3. Index of species biodiversity in sago palm group in Seram island, Maluku province

\begin{tabular}{llcccc}
\hline \multirow{2}{*}{ No. } & $\begin{array}{l}\text { Growth } \\
\text { Phase }\end{array}$ & $\begin{array}{c}\text { Sample I area } \\
\text { Luhu-WS }\end{array}$ & $\begin{array}{c}\text { Sampel II area } \\
\text { Sawai-CM }\end{array}$ & $\begin{array}{c}\text { Sample III area } \\
\text { Werinama-ES }\end{array}$ & Mean \\
\hline 1. & Tree & 0.61 & 0.61 & 0.65 & 0.62 \\
2. & Pole & 0.64 & 0.68 & 0.89 & 0.74 \\
3. & Weaning & 0.75 & 0.71 & 0.90 & 0.79 \\
4. & Seedling & 1.18 & 0.92 & 0.95 & 1.02 \\
\hline & Mean & 0.79 & 0.73 & 0.85 & 0.79 \\
\hline
\end{tabular}

Note: Data described was taken from mean data of sampel I area of Luhu Western Seram, sample II area of Sawai Central Maluku, and sample III area of Werinama Eastern Seram, 2009.

The result of the analysis depicted on Table 3 is considered relevant to argument of Barbour et al. (1987) stated that there is a low index of species biodiversity in all sample areas and growth phase. He also argues that the species biodiversity is included in relatively similar category. It showed that the environment of habitat in sample regions are relatively homogenous and it means some intrusions will not drastically cause significant detriment.

\section{Biodiversity of Genetic Level}

The result of enzyme analysis or enzyme isolation showed some interpretation obtained from three dye enzymes out of four. They were enzyme of AAT, ACP, and PER. On the other hand, the dye process used enzyme of Esterase (EST) resulted imperfect dye process. The three kinds of dye enzyme resulted good interpretation can be described as follow in Figure 2 .
Figure 2 clearly illustrated the trend of isozyme bands from five analyzed sago species and it showed only two bands isozyme trends. Species M. rumphii Mart., M. sylvestre Mart., M. longispinum Mart., and $M$. micrtocanthum Mart. form isozyme band trends into one specific group, while M. sagu Rottb. separately forms its own bands trend. Four sagu species forming the first isozyme bands trend was clearly the sago species with thorn. The second isozyme band trend was $M$. sagu Rottb. which stands for the non-thorn sago species. It concluded that there were only two kinds of sago species cultivating and growing in Seram Island, Maluku Province from knowingly five kinds of sagu species after all. These both two species by Beccari (1918) in Flach (1997) are catagorized into species of Metroxylon rumphii Mart. for the thorny one and Metroxylon sagu Rottb. for those non-thorn sago species. It is also showed that the 


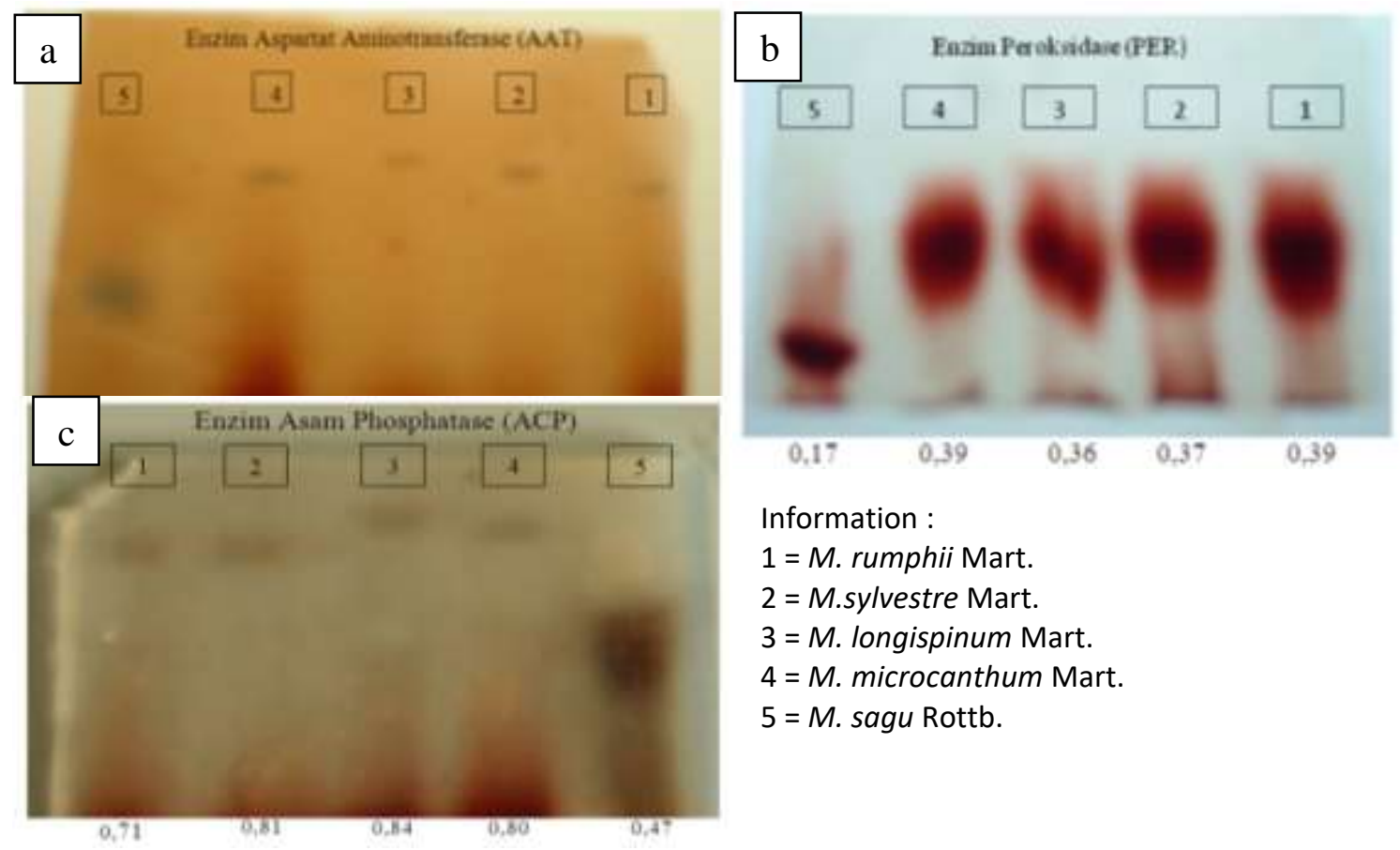

Figure 2. Zimogram of isozyme (a) Aspartat Aminotransferase (AAT), (b) Asam Phosphatase (ACP), and (c) Peroksidase (PER)

Based on Sarkar (1970) in Flach (1997), he stated that there were 16 chromosomes found in sagu palm $(2 n=32)$. The number was supported by the research of Verhaar (1976) in Flach (1997) who found out that non-thorn sago species (M. sagu Rottb.) has chromosomes as many as $13(2 n=26)$. Thus, it can be concluded that thorn sago species M. rumphii Mart has 16 chromosomes and another species $M$. sagu Rottb. has clearly 13 chromosomes.

As it is explained previously, from all five sago species spread all over the world, two of them, $M$. rumphii Mart. and $M$. sagu Rottb., were cultivated and grown in Seram Island, Maluku Province. Then Beccari (1918) in Flach (1997) grouped these two species into four varieties. M. rumphii Mart. consisted of three varieties i.e. 1) Microcanthum Becc., 2) Sylvestre Becc., and 3) Rotang Becc. The another one sago species M. sagu Rottb. solely has one variety i.e. Molat Becc. Further, division of variety
Microcanthum was divided into two subvarieties i.e. Tuni and Makanaro. The result of genetic analysis using isozyme reinforce more argument of Beccari statement that the classification system in sago species was named after biological species terminology.

Based on the recent research above, there is a scientific correction about the amount of sago species located in Seram Island, Maluku Province, Indonesia. It can be explored also from the research that according to Botanica Sistematica issued by FAO (2007), the sago species $M$. longispinum Mart., M. microcanthum Mart, and $M$. sylvestre Mart had not existed from the eight sago species classification spread all over the world. Additionaly, there are only two kinds of sago species i.e. M. rumphii Mart. and $M$. elatum Mart. made by Martius (1838) in FAO (2007). The total numbers of sago species according to Beccari (1918) in Flach (1997) and other marked experts are 
illustrated below in Figure 3. Particular case took place in Molat variety from $M$. sagu Rottb. species as mentioned previously by Beccari (1918) in Flach (1997). It was still in line to the result of sago genetic research conducted in PNG by Kjaer et al. (2004) using AFLP methods that taxonomically $M$. sagu species merely consisted of one single species. Further, he also explained that morphology distribution pattern geographically unreflected genetic variety pattern. It means there was morphological differences in $M$. sagu Rottb. species and the morphological similarity in all areas of PNG unaffected the genetic difference.

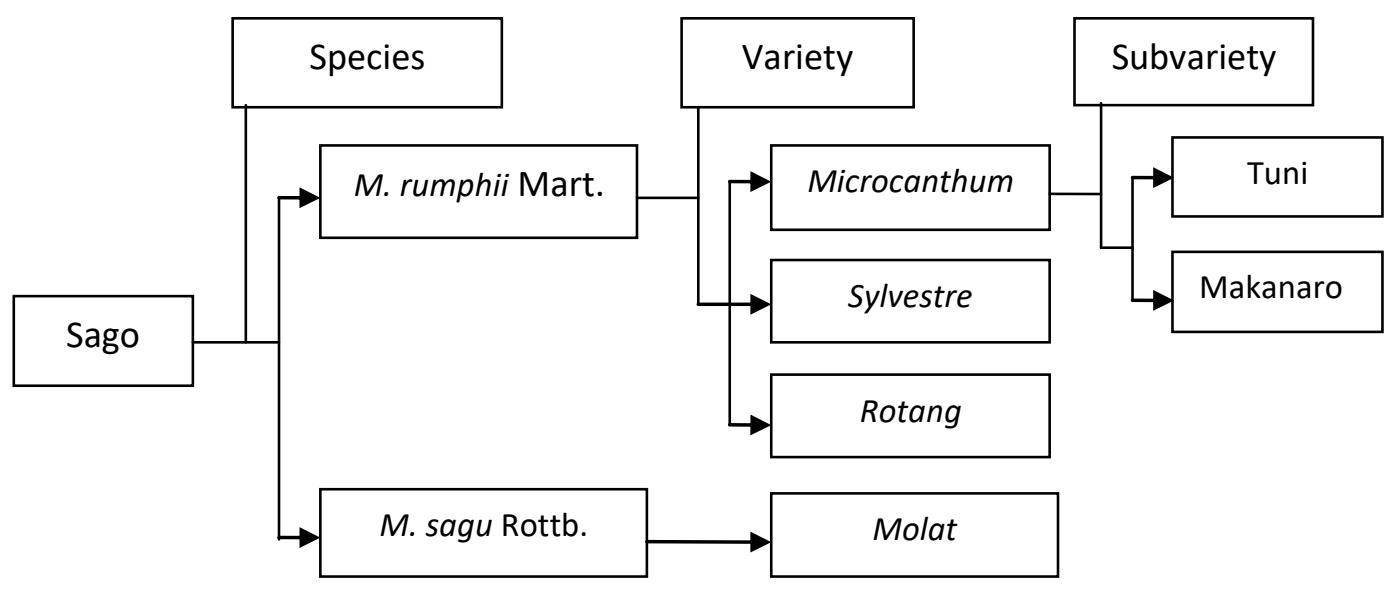

Figure 3. The Numbers of Sago Species in Seram Island, Maluku Province According to Beccari (1918) in Flach (1997).

\section{CONCLUSION}

Based on the classification in biology species, sago palm cultivating and growing in Seram Island, Maluku Province consisted of two species i.e. 1) Metroxylon rumphii Mart., and 2) Metroxylon sagu Rottb. Species $M$. rumphii Mart. consisted of three varieties i.e. 1) Microcanthum Becc., 2) Sylvestre Becc., and 3) Variety of Rotang Becc. Species of $M$. sagu Rottb. only has the variety Molat. Microcanthum has two subvarieties i.e. Tuni and Makanaro. The genetic analysis was considered important to do using specific marker to strengthen or test the accuracy of clarification test for the existed species whether it is in Seram Island in Maluku Province or other regions as well.

\section{REFERENCES}

Barbour GM, Burk JK, Pitts WD. (1987). Terrestrial plant ecology. New York: Benyamin/Cumming Publishing. Inc.

Bintoro HMH. (2008). Bercocok tanam sagu. Bogor : IPB Press (in Indonesian).

[FAO] Food and Agriculture Organization. (2007). Botanica sistematica. http: //www.homolaicus.com/scienza/erb ario/utility/botanica_sistematica/hy pertext/1251.htm. [21 Februari 2010].

Flach M. (1997). Promoting the conservation and use of underutilized and neglected crops. sago palm, Metroxylon sagu, Rottb. Wageningen Agriculture University, Netherlands. International Plant Genetic Resources Institute, Rome. pp 76. http://www.ipgri.cgiar.org/ Publications/ pdf/238.pdf. [11 Agustus 2008]. 
Haryanto B, Pangloli P. (1992). Potensi dan pemanfaatan sagu. Yogyakarta : Kanisus (in Indonesian).

Hartana A. (2003). Elektroforesis sebagai alat pelacak marka molekul biologi. Materi pelatihan singkat Teknik Analisis dengan Metode dan Peralatan mutakhir di Bidang Hayati dan Kimia. Kerjasama antara Pusat Studi Ilmu Hayati Lembaga Penelitian IPB dengan Direktorat Jenderal Pendidikan Tinggi, Departemen Pendidikan Nasional. Bogor, 21-25 Oktober 2003. hlm 2531 (in Indonesian).

Kartono AP. (2006). Ekologi kuantitatif konservasi keanekaragaman hayati. Laboratorium Ekologi Satwaliar, Departemen Konservasi Sumberdaya Hutan dan Ekowisata. Fakultas Kehutanan IPB (tidak dipublikasikan) (in Indonesian).

Kjaer A, Barfodi A, Asmussen CB, Seberg O. (2004). Investigation of genetic and morphological variation in the sago palm (Metroxylon sagu; Arecaceae) in Papua Newe Guinea. J Ann Bot 94 (1) : 109-117.

Krebs CJ. (1999). Ecological Methodology. Canada : Addison-Welsey Longman, Inc.

Louhenapessy JE. (2006). Potensi dan Pengelolaan sagu di Maluku. Makalah disampaikan pada Lokakarya Sagu dengan tema Sagu dalam Revitalisasi Pertanian Maluku. Ambon 29-31 Mei 2006 (in Indonesian).

Ludwig AJ, \& Reynolds JF. (1988). Statistical Ecology. A Primer on methods and computing. New York : John Willey \& Sons.

McClatchey W, Manner HI, Elevitch CR. (2006). Metroxylon amicarum, $M$. paulcoxii, M. sagu, M. salomonense,
M. vitiense, and $M$. warburgii (sago palm). Species Profile for Pacific Island Agroforestry. Traditional Tree Initiative. http://www.agroforestry. net/tti/Metroxylon-sagopalm.pdf. [7 Agustus 2008].

Notohadiprawiro T, Louhenapessy JE. (1993). Potensi sagu dalam penganekaragaman bahan pangan pokok ditinjau dari persyaratan lahan. Prosiding Simposium Sagu Nasional, "Pemanfaatan dan Pengelolaan Hutan Sagu dalam Rangka Pengembangan Bagian Timur Wilayah Indoensia Khususnya Provinsi Maluku", Ambon, 12-13 Oktober 1992. Ambon : Fakultas Pertanian Universitas Pattimura. hlm 99-106 (in Indonesian).

Rostiwati T et al. (2008). Sagu (Metroxylon spp) sebagai sumber energi bioetanol potensial. Pusat Penelitian dan Pengembangan Hutan Tanaman, Badan Penelitian dan Pengembangan Kehutanan, Departemen Kehutanan (in Indonesian).

Setiadi D. (2005). Keanekaragaman spesies tingkat pohon di Taman Wisata Alam Ruteng, Nusa Tenggara Timur. J Biodiversitas 6 (2) : 118-122 (in Indonesian).

Setiadi D, Muhadiono I, Yusron A. (1989). Penuntun Praktikum Ekologi. Departemen Pendidikan dan Kebudayaan, Direktorat Jenderal Pendidikan Tinggi, Pusat Antar Universitas Ilmu Hayat, Institut Pertanian Bogor. Bogor (in Indonesian).

Soegianto A. (1994). Ekologi Kuantitatif, Metode Analisis Populasi dan Komunitas. Surabaya : Usaha Nasional (in Indonesian). 